\title{
ПІДСТАВИ ВИЗНАННЯ ДОКАЗІВ НЕДОПУСТИМИМИ У КОНТЕКСТІ СТАНДАРТІВ ЇХ ДОПУСТИМОСТІ: ЗАКОНОДАВЧИЙ ПІДХІД І ПРАКТИКА ВЕРХОВНОГО СУДУ
}

\author{
КРЕТ Галина Романівна - суддя Касаційного кримінального суду у складі \\ Верховного Суду, кандидат юридичних наук, доцент
}

DOI:10.32782/LAW.2020.1.20

УДК 343.14

Статья посвящена раскрьттию оснований признания доказательств недопустимылм в контексте стандартов их допустимости. На основе анализа норм уголовного процессуального закона осуществляется классификация оснований признания доказательств недопустимъими. С учетом норм УПК Украинъ и судебной практики Верховного Суда приводятся основания признания доказательств недопустимълми, охватьиваюшиеся каждой из вълделеннъх групп. Указивается на разрешение вопроса о допустимости/недопустимости доказательств на основе внутреннего убеждения суда, ограничивающемся закрепленнъими нормами уголовного процессуального закона существенными нарушениями прав и основнъх свобод человека. Вълделяется ряд аспектов, подлежаших учету судом при разрешении вопроса о недопустимости доказательств вследствие существенного нарушения норм уголовного процессуального закона.

Ключевые слова: стандарты доказывания, стандарть допустимости доказательств, допустимость доказательств, допустимъле доказательства, Верховнъй Суд.

\section{Вступ}

Міжнародні стандарти допустимості доказів закріплені нормами вітчизняного кримінального процесуального закону та широко використовуються у практиці національних судів. Їх впровадження у вітчизняне кримінальне процесуальне законодавство відбулося з прийняттям чин- ного КПК України, в якому законодавець визначив поняття допустимих доказів (ч. 1 ст. 86), закріпив обов'язок суб'єктів доказування здійснити оцінку доказів із точки зору їх допустимості (ч. 1 ст. 94), поклав тягар доказування допустимості доказів на сторону, що їх подає (ч. 2 ст. 92), передбачив низку підстав визнання доказів недопустимими (ст. 87 , ч. 5 ст. 101 , ч. 8 ст. 223, ч. 3 ст. 233 і ч. 12 ст. 290), врегулював особливості визначення допустимості окремих доказів (ст. ст. 88 і 88-1), визначив порядок визнання доказів недопустимими (ст. 89), вказав на преюдиціальне значення рішень судів у питаннях допустимості доказів (ст. 90), поклав на суд апеляційної інстанції обов'язок відображати мотиви визнання окремих доказів недопустимими в ухвалі (п. 2 ч. 1 ст. 419), визначив особливості встановлення допустимості доказів, отриманих під час міжнародного співробітництва під час кримінального провадження (ч. 2 ст. 550 , ч. 2 ст. 553 і ч. 2 ст. 598) та передбачив наслідки визнання доказів недопустимими (ч. 2 ст. 86 і ч. 1 ст. 87).

У доктрині кримінального процесу дослідженню проблематики як допустимості доказів, так і стандартів доказування присвячена істотна увага. Сутність допустимості як процесуальної властивості доказів та підстави, порядок і правові наслідки визнання їх недопустимими розкриваються у працях Н.М. Басай, Г.П. Власової, М.В. Гузели, А.А. Павлишина, В.В. Рож- 


\section{Кримінальне право, кримінальний процес та криміналістика}

нової, Д.Б. Сергєєвої, М.М. Стоянова, В.В. Тютюнника, I. $\wedge$. Чупрікової та інших вчених. Зміст стандартів доказування та особливості їх застосування у кримінальному процесі виступали предметом дослідження у працях В.Д. Басая, В.В. Вапнярчука, I.B. Гловюк, В.О. Гринюка, В.А. Завтура, О.В. Капліної, С.О. Ковальчука, В.І. Мариніва, М.А. Погорецького, Х.P. Слюсарчук, А.С. Степаненка, В.М. Трофименка, О.Г. Шило та інших вчених. Проте, закріплені КПК України і сформовані у судовій практиці стандарти доказування, які стосуються підстав визнання доказів недопустимими, науковцями досліджено фрагментарно.

\section{Постановка завдання}

Метою статті $є$ розкриття на основі норм кримінального процесуального закону та практики Верховного Суду підстав визнання доказів недопустимими у контексті стандартів їх допустимості.

\section{Результати дослідження}

Закладаючи уч. 1 ст. 86 КПК України узагальнюючу умову допустимості доказів - їх отримання у порядку, встановленому цим Кодексом, законодавець у нормах кримінального процесуального закону наводить низку підстав визнання доказів недопустимими. Їх аналіз дозволяє виокремити три групи таких підстав: 1) отримання доказів внаслідок істотного порушення прав та свобод людини; 2) отримання доказів внаслідок інших істотних порушень норм кримінального процесуального закону; 3) допущення істотних порушень норм кримінального процесуального закону, які не пов’язані з отриманням доказів.

у межах першої групи законодавець вказує на недопустимість доказів, отриманих внаслідок істотного порушення прав та свобод людини, гарантованих Конституцією та законами України, міжнародними договорами, згода на обов'язковість яких надана Верховною Радою України, а також будь-яких інших доказів, здобутих завдяки інформації, отриманій внаслідок істотного порушення прав та свобод людини (ч. 1 ст. 87 КПК України) [1]. Підстави визнання доказів недопустимими вна- слідок істотного порушення прав людини і основоположних свобод визначаються у ч. 2 ст. 87 КПК України і широко використовуються у судовій практиці. При цьому, окремі 3 них, 3 огляду на їх узагальнене формулювання, знаходять уточнення 3 урахуванням норм кримінального процесуального закону, порушення яких було допущене під час досудового розслідування або судового розгляду. Так, істотними порушеннями права на захист, які призводять до недопустимості доказів, у судовій практиці визнаються: 1) проведення слідчих (розшукових) дій за участю підозрюваного без залучення захисника у випадках, коли участь останнього у кримінальному провадженні є обов'язковою [14]; 2) проведення слідчих (розшукових) дій за участю підозрюваного за відсутності залученого ним захисника поза наявністю у матеріалах кримінального провадження даних про його повідомлення про час та місце проведення відповідних дій і про причини неявки [21]; 3) незалучення захисника та законного представника до участі у слідчих (розшукових) діях за участю затриманого неповнолітнього [13] тощо.

До другої групи належать підстави, які вказують на отримання доказів внаслідок інших істотних порушень норм кримінального процесуального закону. Зазначена група включає, по-перше, підстави, передбачені ч. 3 ст. 87 КПК України, оскільки наведені у ній порушення не пов'язані з істотним порушенням прав та свобод людини, а по-друге, підстави, які прямо або опосередковано закріплені іншими нормами КПК України (зокрема, ч. 8 ст. 223 і ч. 3 ст. 233) та свідчать про істотність порушення норм кримінального процесуального закону. Наведені у вказаних нормах кримінального процесуального закону підстави визнання доказів недопустимими використовуються у судовій практиці, хоча й менш широко, ніж підстави, визначені ч. 2 ст. 87 КПК України. Це пов'язано як з конкретизованістю переважної більшості зазначених підстав (п. п. 3 і 4 ч. 3 ст. 87 , ч. 8 ст. 223 і ч. 3 ст. 233 КПК України), так і недієвістю окремих 3 них під час судового розгляду (п. 1 ч. 3 ст. 
87 КПК України). При цьому узагальнене формулювання законодавцем підстави, передбаченої п. 2 ч. 3 ст. 87 КПК України, призвело до виокремлення у судовій практиці низки істотних порушень норм кримінального процесуального закону, які призводять до визнання доказів недопустимими. До числа таких порушень, зокрема, належать: 1) прийняття рішення про проведення контролю за вчиненням злочину начальником відділення поліції, а не прокурором [18]; 2) провокація (підбурювання) особи на вчинення цього злочину 3 метою його подальшого викриття [10]; 3) проведення негласних слідчих (розшукових) дій, які можуть здійснюватися у кримінальному провадженні щодо тяжких або особливо тяжких злочинів, під час досудового розслідування злочинів невеликої та середньої тяжкості [8].

Водночас, закріплений наведеними нормами кримінального процесуального закону перелік істотних порушень, які призводять до визнання доказів недопустимими, не є вичерпним. На це звертає увагу Верховний Суд у контексті аналізу підстав визнання доказів недопустимими, визначених ч. ч. 2 і 3 ст. 87 КПК України. Так, на думку Верховного Суду, перелік діянь, які передбачені у ст. 87 КПК України як підстави для визнання фактичних даних недопустимими як докази, не є вичерпним i становить собою порушення фундаментальних гарантій, що дає певний орієнтир для визначення змісту поняття «істотне порушення» у випадках, які не підпадають під цей перелік [11].

Як свідчать результати дослідження судової практики, звертаючись до вирішення питання про допустимість доказів, суди визнають їх недопустимими як $з$ підстав, визначених ч. ч. 2 і 3 ст. 87 , ч. 8 ст. 223 і ч. 3 ст. 233 КПК України, так і з інших підстав, які, на їх думку, свідчать про істотні порушення норм кримінального процесуального закону, допущені у ході отримання доказів, зокрема: 1) отримання доказів 3 висновку спеціаліста [12]; 2) отримання доказів винуватості з тверджень і заяв підозрюваного, обвинуваченого, зроблених під час розгляду клопотання про засто- сування запобіжного заходу [7]; 3) отримання доказів з пояснень особи, наданих експерту під час проведення експертизи, зокрема у ході проведення судово-психіатричної експертизи, хоча у наведеному випадку констатується порушення п. 4 ч. 2 ст. 87 КПК України [5]; 4) отримання доказів слідчим, який не був призначений керівником органу досудового розслідування [19] або не був включений до складу групи слідчих у кримінальному провадженні [24] чи прокурором, який не був призначений керівником відповідного органу прокуратури або включений до складу групи прокурорів, які здійснювали повноваження прокурорів у конкретному кримінальному провадженні [25]; 5) отримання доказів оперативним підрозділом у результаті проведення негласних слідчих (розшукових) дій без доручення слідчого [23]; 6) одержання доказів до внесення відомостей до ЕРДР, крім випадків їх отримання в ході проведення у невідкладних випадках огляду місця події, та порушення вимоги щодо негайного внесення відомостей до ЕРДР після завершення огляду [4]; 7) відсутність або недобровільність згоди особи на проникнення до іiі житла чи іншого володіння, крім випадків проникнення на підставі ухвали слідчого судді або у невідкладних випадках до їі постановлення [17]; 8) проведення слідчих (розшукових) дій без участі понятих за умови обов’язковості їх запрошення у відповідній дії [11] або за участю понятих, які можуть бути заінтересованими у результатах вирішення справи, зокрема, потерпілого [3] та представника потерпілого [16]; 9) складення висновку експерта особою, яка не мала права проводити експертизу [15], у тому числі у випадку непопередження експерта про кримінальну відповідальність за дачу завідомо неправдивого висновку та втрати чинності свідоцтвом на право проведення експертних досліджень і непродовження їх дії [9] тощо.

Третя група включає підстави, пов'язані 3 допущенням істотних порушень норм кримінального процесуального закону, які не стосуються отримання доказів. До їх числа входять, по-перше, не- 


\section{Кримінальне право, кримінальний процес та криміналістика}

відкриття матеріалів кримінального провадження у порядку ст. 290 КПК України, а по-друге, порушення закріплених ч. 1 ст. 88, ст. 88-1 і ч. 1 ст. 257 КПК України правил використання окремих доказів. Наприклад, надаючи оцінку законності й обгрунтованості вироку суду першої інстанції, Верховний Суд вказує, що у матеріалах кримінального провадження відсутня відповідна ухвала слідчого судді про використання результатів вказаних негласних слідчих дій (контролю за вчинення злочину у формі оперативної закупки наркотичного засобу - Г.К.) в іншому кримінальному провадженні, як того вимагає ст. 257 КПК України, тому всі докази, здобуті внаслідок проведених негласних слідчих дій відносно інших осіб (ОСОБА_5 та ОСОБА_6) суд правильно визнав недопустимими. У зв'язку з цим, колегія суддів погодилася $з$ висновком суду першої інстанції про недопустимість таких доказів, з огляду на положення ст. ст. 86 і 87 КПК України та вважала, що у зв'язку з зазначеним суд дійшов обгрунтованого висновку про недоведеність вчинення кримінальних правопорушень обвинуваченими ОСОБА_1 та ОСОБА_2 [2].

Аналізуючи закріплені нормами кримінального процесуального закону та сформовані у судовій практиці підстави визнання доказів недопустимими, потрібно вказати, що істотність порушення норм кримінального процесуального закону $\epsilon$ оціночним поняттям. На це у контексті аналізу істотних порушень прав і свобод людини звертає увагу Верховний Суд, який вказує, що поняття істотного порушення прав і свобод людини є оціночним. У кожній конкретній ситуації, з урахуванням фактичних обставин справи та отримання доказів, суд в нарадчій кімнаті під час ухвалення судового рішення, надає оцінку допустимості кожного доказу [22]. У зв'язку з цим вирішення питання про допустимість/недопустимість доказу у кожному конкретному випадку покладається на розсуд суду. При цьому, як обгрунтовано вказує В.В. Терьохін, припис законодавця про допустимість доказів не має ніякого іншого змісту, крім того, що зро- зумів і визнав придатним до застосування суд, зважаючи на необхідність вирішення кримінальної справи по суті та вирішення окремого спірного питання [26, с. 19].

Вирішуючи питання про допустимість/ недопустимість доказів суд повинен враховувати низку аспектів, більшість яких сформована у практиці Верховного Суду.

По-перше, суд має враховувати позицію сторін кримінального провадження стосовно допустимості доказів. У контексті оцінки викладених у касаційній скарзі доводів сторони захисту стосовно недопустимості протоколів слідчих експериментів зі свідками і відповідних відеозаписів, Верховний Суд вказав на неприпустимість порушення питання про недопустимість доказів у касаційній інстанції 3 огляду на їх дослідження судом першої інстанції за згодою сторони захисту. При цьому Верховний Суд відзначив, що суд під час розгляду справи не може втручатися у стратегію і тактику, обрану стороною захисту, особливо в питаннях дослідження доказів. Якщо сторона не заперечує проти дослідження певного доказу, який міг би бути оспорений з точки зору його допустимості, суд не вправі втручатися у такий спосіб відстоювання стороною своєї позиції. Сторона не може спочатку погоджуватися 3 необхідністю дослідження в суді доказів, сподіваючись за їх допомогою обгрунтувати свою позицію, а згодом, - коли ця тактика не дала очікуваних результатів, заперечувати проти допустимості цих же доказів [6].

По-друге, врахуванню судом підлягають істотність допущеного порушення норм кримінального процесуального закону та наслідки, які воно спричинило. Із позиції Верховного Суду, питання про визнання доказів недопустимими вирішується судом під час їх оцінки в нарадчій кімнаті при ухваленні судового рішення (ч. 1 ст. 89 КПК) у кожному конкретному випадку залежно від характеру і наслідків порушень критеріїв допустимості [11]. При цьому Верховний Суд вказує, що ч. 1 ст. 87 КПК передбачено, що ключовою умовою для визнання доказів недопустимими 6 їх отримання внаслідок істотного 
порушення прав та свобод людини, гарантованих Конституцією та законами України, міжнародними договорами, згода на обов'язковість яких надана Верховною Радою України [20]. Вказана позиція грунтується на нормі ч. 4 ст. 87 КПК України, відповідно до якої докази, передбачені цією статтею, повинні визнаватися судом недопустимими під час будь-якого судового розгляду, крім розгляду, якщо вирішується питання про відповідальність за вчинення зазначеного істотного порушення прав та свобод людини, внаслідок якого такі відомості були отримані [1]. Наслідки порушення норм кримінального процесуального закону мають визначатися, у першу чергу, з урахуванням дотримання прав, свобод і законних інтересів учасників кримінального провадження.

По-третє, суд повинен враховувати значимість доказу для встановлення обставин, які становлять предмет доказування. Як вказує Верховний Суд, у кожному конкретному випадку суд, оцінюючи допустимість того чи іншого доказу, повинен враховувати істотність допущених порушень кримінального процесуального закону та важливість кожного доказу для встановлення обставин кримінального провадження [11]. Необхідність врахування значимості доказу зумовлена покладеним на суд обов'язком всебічно, повно та неупереджено дослідити всі обставини кримінального провадження (ч. 1 ст. 94 КПК України) [1].

По-четверте, суду потрібно враховувати, що визнання доказів недопустимими не призводить до спростування фактів, які підлягають доказуванню та встановлюються, у тому числі, за допомогою цих доказів. Як наголошує Верховний Суд, встановлення судом недопустимості доказів або порушень вимог процесуального закону під час збирання доказів не може повністю спростовувати фактів, які в них зафіксовано, та показання потерпілих та/або свідків [20]. Факт вчинення кримінального правопорушення та обставини його скоєння за своєю природою є об'єктивними та існують незалежно від їх встановлення під час кримінального провадження. Водночас, все- бічне, повне і неупереджене дослідження всіх обставин кримінального провадження та їх підтвердження за допомогою доказів дозволяє суду сформувати внутрішне переконання щодо їх існування, у зв'язку з чим визнання доказів недопустимими позначається на всебічності та повності встановлення цих обставин.

По-п'яте, суд має враховувати наслідки визнання доказу недопустимим у контексті вимог до судового рішення, зокрема його законності, обгрунтованості та справедливості (ч. 3 ст. 337, ст. ст. 370 і 410 КПК України). Як відзначає Верховний Суд, кожний доказ повинен оцінюватися автономно, оскільки його безумовне виключення може призвести до негативних наслідків, що виражатимуться в ухваленні незаконного, необгрунтованого та несправедливого судового рішення [11]. Зокрема, визнання доказу недопустимим може призвести до неповноти судового розгляду або невідповідності висновків суду, викладених у судовому рішенні, фактичним обставинам кримінального провадження.

\section{Висновки}

Аналіз норм кримінального процесуального закону та сформованої на їх основі судової практики свідчить, що вирішення питання про допустимість/недопустимість доказів здійснюється на основі внутрішнього переконання суду, яке обмежується закріпленими нормами кримінального процесуального закону істотними порушеннями прав та основоположних свобод людини. Під час вирішення питання про недопустимість доказів внаслідок істотного порушення норм кримінального процесуального закону врахуванню судом підлягають: 1) позиція сторін кримінального провадження стосовно допустимості доказів; 2) істотність допущеного порушення норм кримінального процесуального закону та наслідки, які воно спричинило; 3) значимість доказу для встановлення обставин, які становлять предмет доказування; 4) визнання доказів недопустимими не призводить до спростування фактів, які підлягають доказуванню; 5) наслідки визнання доказу недопустимим у контексті 


\section{Кримінальне право, кримінальний процес та криміналістика}

вимог до судового рішення, зокрема його законності, обгрунтованості та справедливості.

\section{Література}

1. Кримінальний процесуальний кодекс України від 13.04.2012 р. № 4651VI. URL: http://zakon5.rada.gov.ua/laws/ show/4651-17.

2. Постанова Верховного Суду від 21.03.2018 р. у справі № 751/7177/14 (провадження № 51-1285км18). URL: http:// reyestr.court.gov.ua/Review/72938764.

3. Постанова Верховного Суду від 29.03.2018 р. у справі № 459/2045/15-к (провадження № 51-769км18). URL: http:// reyestr.court.gov.ua/Review/73189758.

4. Постанова Верховного Суду від 12.04 .2018 р. у справі № 366/1400/15к (провадження № 51-1528км18). URL: http://reyestr.court.gov.ua/Review/73438093.

5. Постанова Верховного Суду від 26.04 .2018 р. у справі № $135 / 1530 / 16-\kappa$ (провадження № 51-447км17). URL: http:// reyestr.court.gov.ua/Review/73758522.

6. Постанова Верховного Суду від 22.05.2018 р. у справі № 459/3331/16-к (провадження № 51-43км18). URL: http:// www.reyestr.court.gov.ua/Review/74551561.

7. Постанова Верховного Суду від 24.05.2018 р. у справі № 401/206/16-к (провадження № 51-1080км18). URL: http:// reyestr.court.gov.ua/Review/74376393.

8. Постанова Верховного Суду від 07.06.2018 р. у справі № 604/1071/14-к (провадження № 51-809км18). URL: http:// reyestr.court.gov.ua/Review/74630432.

9. Постанова Верховного Суду від 12.06.2018 p. у справі № 367/2556/16к (провадження № 51-1926км18). URL: http://reyestr.court.gov.ua/Review/74747664.

10. Постанова Верховного Суду від 19.06 .2018 р. у справі № 266/2586/15-к (провадження № 51-994км18). URL: http:// reyestr.court.gov.ua/Review/74842743.

11. Постанова Верховного Суду від 25.09.2018 р. у справі № 210/4412/15-к (провадження № 51-80км17). URL: http:// reyestr.court.gov.ua/Review/76859981.

12. Постанова Верховного Суду від 27.09.2018 р. у справі № 533/93/16-к (про- вадження № 51-4186км18). URL: http:// reyestr.court.gov.ua/Review/76945360.

13. Постанова Верховного Суду від 23.10 .2018 р. у справі № 158/2313/15к (провадження № 51-3021км18). URL: http://reyestr.court.gov.ua/Review/77393408.

14. Постанова Верховного Суду від 25.10.2018 р. у справі № 562/2333/15-к (провадження № 51-4953км18). URL: http:// www.reyestr.court.gov.ua/Review/77586813.

15. Постанова Верховного Суду від 20.11.2018 р. у справі № 290/738/15-к (провадження № 51-4 км 17). URL: http://reyestr. court.gov.ua/Review/78267939.

16. Постанова Верховного Суду від 22.11 .2018 р. у справі № 194/1437/15к (провадження № 51-1913км18). URL: http://reyestr.court.gov.ua/Review/78297771.

17. Постанова Верховного Суду від 12.02.2019 р. у справі № 159/451/16-к (провадження № 51-1173км18). URL: http:// reyestr.court.gov.ua/Review/80224144.

18. Постанова Верховного Суду від 26.03.2019 р. у справі № 554/5204/17 (провадження № 51-6569км18). URL: http:// reyestr.court.gov.ua/Review/80889388.

19. Постанова Верховного Суду від 04.04.2019 р. у справі № 754/11898/14к (провадження № 51-5959км18). URL: http://reyestr.court.gov.ua/Review/81107597.

20. Постанова Верховного Суду від 11.04 .2019 р. у справі № 642/5974/13к (провадження № 51-7304км18). URL: http://reyestr.court.gov.ua/Review/81264179.

21. Постанова Верховного Суду від 20.06.2019 р. у справі № 607/12579/17к (провадження № 51-10151км18). URL: http://reyestr.court.gov.ua/Review/82636244.

22. Постанова Верховного Суду від 27.06.2019 р. у справі № 754/4515/16к (провадження № 51-8214км18). URL: http://reyestr.court.gov.ua/Review/82826959.

23. Постанова Верховного Суду від 05.11 .2019 р. у справі № 344/11299/15к (провадження № 51-1009км19). URL: http://reyestr.court.gov.ua/Review/85743614.

24. Постанова Верховного Суду від 29.01.2020 р. у справі № 473/3712/18 (провадження № 51-4540км19). URL: http:// reyestr.court.gov.ua/Review/87365800.

25. Постанова Верховного Суду від 


\begin{tabular}{|c|}
\hline $\begin{array}{l}\text { АНОТАЦІЯ } \\
\text { Стаття присвячена розкриттю підстав } \\
\text { визнання доказів недопустимими у контексті } \\
\text { стандартів їх допустимості. На основі аналі- } \\
\text { зу норм кримінального процесуального закону } \\
\text { здіиснюється класифікаиія підстав визнання } \\
\text { доказів недопустимими. З урахуванням норм } \\
\text { КПк Украӥни і судової практики Верховного } \\
\text { Суду наводяться підстави визнання доказів } \\
\text { недопустимими, які охоплюються кожною з } \\
\text { виокремлених груп. Вказується на вирішення } \\
\text { питання про допустимість/недопустимість } \\
\text { доказів на основі внутрішнього переконання } \\
\text { суду, яке обмежується закріпленими нормами } \\
\text { кримінального прочесуального закону істот- } \\
\text { ними порушеннями прав та основоположних } \\
\text { свобод людини. Виокремлюється низка ас- } \\
\text { пектів, які підлягють врахуванню судом під } \\
\text { час вирішення питання про недопустимість } \\
\text { доказів внаслідок істотного порушення норм } \\
\text { кримінального прочесуального закону. } \\
\text { Ключові слова: стандарти доказування, } \\
\text { стандарти допустимості доказів, допусти- } \\
\text { мість доказів, допустимі докази, Верховний } \\
\text { Суд. }\end{array}$ \\
\hline
\end{tabular}

11.02.2020 р. у справі № 761/33311/15-к (провадження № 51-487км18). URL: http:// www.reyestr.court.gov.ua/Review/87672462.

26. Терехин В.В. Допустимость доказательств в уголовном процессе (методологический, правовой, этический аспекты): автореф. дисс. ... д-ра юрид. наук: 12.00.09. Нижний Новгород, 2016. 52 с.

\section{SUMMARY}

The article is devoted to the research of grounds for the recognition of evidences inadmissible in the context of standards of their admissibility.

On the basis of the analysis of the rules of criminal procedural law the grounds for the recognition of evidences inadmissible are classified into three groups: 1) obtaining evidences as a result of a significant violation of human rights and freedoms; 2) obtaining evidences as a result of other significant violations of the rules of criminal procedural law; 3) admission of significant violations of the rules of criminal procedural law that are not related to the obtaining of evidences. Taking into account the norms of the Criminal Procedural Code of Ukraine and the Supreme Court's jurisprudence, the grounds for the recognition of evidences inadmissible, which are covered by each of the selected groups, are given.

It is indicated that the issue of admissibility/ inadmissibility of evidences based on the internal conviction of a court, which is limited by significant violations of human rights and fundamental freedoms fixed in the rules of criminal procedural law.

It is pointed a number of aspects to be considered by the court in deciding the inadmissibility of evidences due to significant violations of the rules of criminal procedural law are distinguished, namely: 1) the position of the parties of criminal proceedings regarding the admissibility of evidences; 2) the materiality of the violation of the rules of criminal procedural law and the consequences it caused; 3) the significance of the evidence to establish the circumstances that constitute the subject of proof; 4) the admission of evidences inadmissible does not lead to the refutation of the facts to be proved; 5) the consequences of the admission of evidences inadmissible in the context of the requirements for a judicial decision, in particular its legality, validity and fairness.

Keywords: standards of proof, standards of admissibility of evidences, admissibility of evidences, admissible evidences, Supreme Court. 